\title{
Dietary guidelines for the breast-feeding woman
}

\author{
Pilar Cervera* and Joy Ngo \\ Centre d'Ensenyament Superior de Nutrició i Dietètica (CESNID), University of Barcelona, La Masia, Av. de Prat de \\ la Riba 171, E-08921 Santa Coloma de Gramenet, Barcelona, Spain
}

\begin{abstract}
Sociodemographic and economic changes in Spain have played a role in the choice of infant feeding as more and more women enter the workforce. Nevertheless, the prevalence of breast-fed-only infants at 6 weeks remains fairly high, at 65.5\% in 1999, although there is a sharp decline by 3 and 6 months postpartum. Achieving adequate nutritional status for lactation principally begins during pregnancy, as this constitutes the biological stage for accumulating nutrient stores. The benefits of breast-feeding for the mother and infant are presented, along with nutrition and dietary guidelines for the nursing woman. Apart from dietary considerations, special attention should be paid to encouraging a positive attitude and environment for breast-feeding success.
\end{abstract}

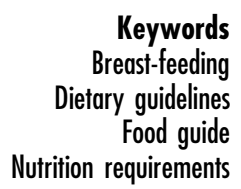

Lactation is defined as the period of the newborn infant's life in which breast-milk is the primary source of nourishment. Breast-milk is the food that provides the infant with all of the necessary elements to meet nutritional needs. Mammalian milk is characterised by its inclusion of all nutritive substances in the exact proportions and balance unique to each species. Such is the case with human milk ${ }^{1}$.

Until the 19th century, when mothers were no longer able or preferred not to raise their offspring, the practice of using wet nurses was widespread. These women would breast-feed not only their own children but also those of other mothers, so that these infants would continue receiving breast-milk. Although archaeological artefacts show the existence of utensils similar to modernday baby bottles, it is widely accepted that the appearance of industrially prepared infant formula milk is a contemporary phenomenon. These preparations are elaborated using derivatives of mammalian milk other than humans', principally that of cows.

The possibilities offered by today's modern technology have made a plethora of products available to the consumer. Some of these artificial formulas are, without a doubt, indispensable in specific cases. However, when no definite contraindication for breast-feeding exists, mother's milk is clearly superior and specific for human infants ${ }^{2}$.

In Spain, many sociodemographic as well as economic changes have occurred in the past decades. The role of women has also been affected, as seen by their increased participation in the labour force and subsequent changes. Although, in general, limited data are available for patterns in infant feeding practices, a study carried out in Madrid demonstrated that Spain followed the general decline in breast-feeding incidence that took place in Western countries in the 1960s and 1970s, with a subsequent upwards trend that continues to the present ${ }^{3}$. Figure 1 shows more recent national trends in infant feeding practices. Breast-feeding prevalence appears to have improved at 6 weeks, 3 months and 6 months. However, this does not negate the phenomenon of a sharp decline of exclusive breast-feeding by 6 months (65.5\% at 6 weeks, $43.8 \%$ at 3 months and $21.2 \%$ at 6 months) with a concomitant increase in breast-milk substitutes ${ }^{4,5}$. This could be explained by the fact that, in Spain, the percentage of women in the workforce has increased from 28\% in 1986 to $39 \%$, and that paid maternity leave consists of a period of four months ${ }^{6}$.

\section{Human milk}

Breast-milk is the ideal food for newborn infants and, as such, respecting an individual's freedom of choice, constitutes the preferred method of infant feeding. Studies show that breast-fed infants have fewer problems with infectious and non-infectious diseases, and experience milder cases of respiratory and ear infections as well as diarrhoea than non-breast-fed babies ${ }^{7}$. The specificity of breast-milk's components for the human infant makes it the ideal food for meeting nutrient needs for growth and development. This can be seen, for example, in its lower total protein and casein content when compared with cow's milk, which makes human milk more digestible and less demanding for infants' immature kidneys ${ }^{8}$. Other studies suggest that the lower weight gain pattern seen in breast-fed infants in the first year of life, accompanied by 


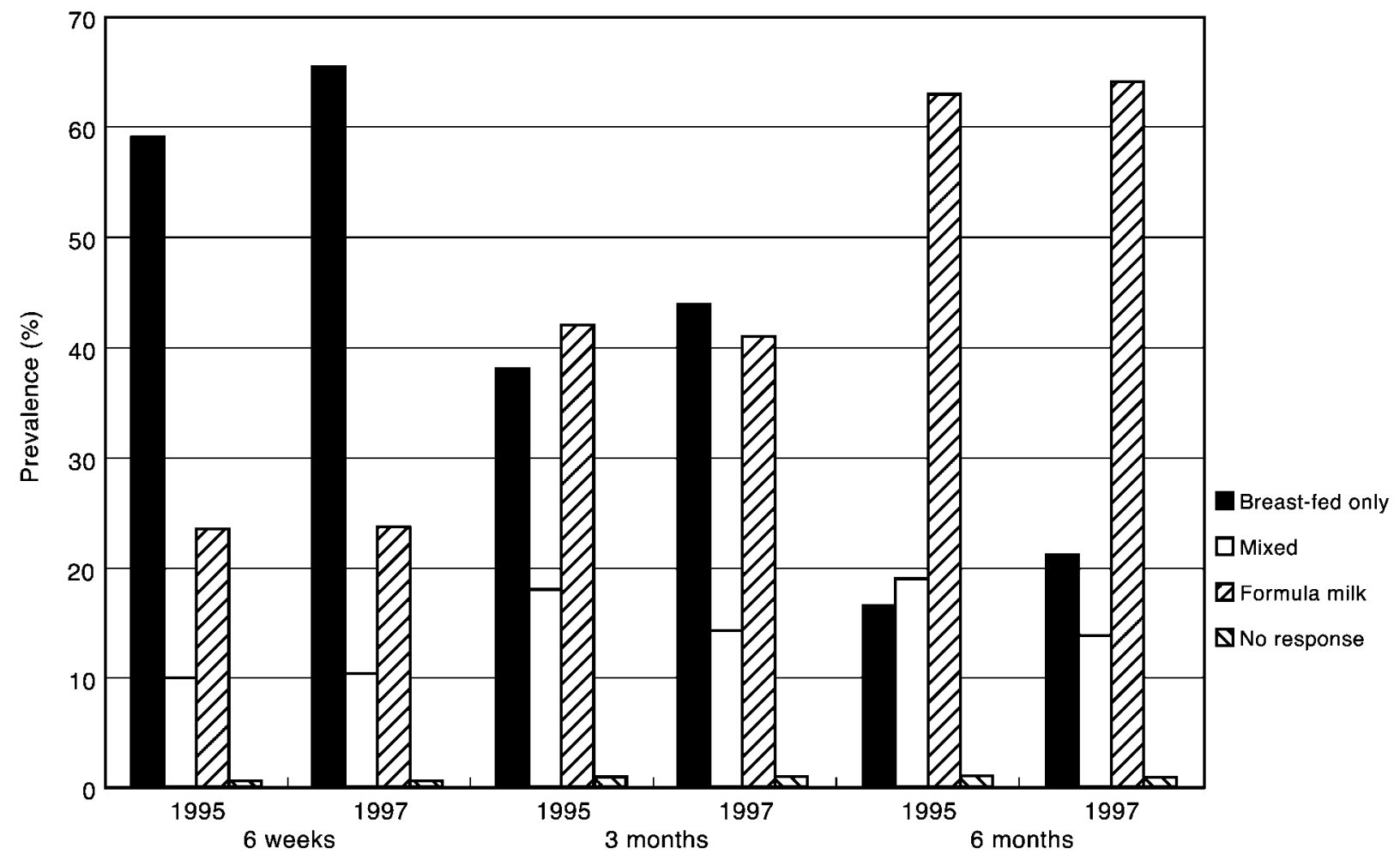

Fig. 1 Breast-feeding prevalence in Spain ${ }^{4,5}$

normal activity and development, may lead to less overweight and obesity in childhood and adulthood ${ }^{9-11}$.

Further evidence has demonstrated that breast-feeding may have beneficial effects on reduced chronic disease risk and enhanced development. Recent studies show potential relationships between breast-feeding and decreased risk for celiac disease, inflammatory bowel disease, type 1 and 2 diabetes, childhood cancer and allergic disorders/asthma ${ }^{12-22}$. Other investigators provide stimulating evidence for a positive association between breast-milk and cognitive evolution, particularly for the long-chain polyunsaturated fatty acids (PUFAs) found in human milk and their role in infant brain growth and development ${ }^{23-26}$.

A nursing mother also benefits from breast-feeding. The increased level of the hormone oxytocin promotes expulsion of the placenta, minimises postpartum blood loss, and facilitates a more rapid uterine involution ${ }^{27}$. Psychological benefits may also be manifested, such as increased self-esteem, and enhanced bonding between mother and infant ${ }^{28-30}$. Additionally, breast-feeding can save several hundred dollars (US) from the costs of purchasing infant formula milk, even factoring in expenditures for breast pump equipment and increased food requirements of the breast-feeding mother ${ }^{31}$. A costbenefit study has demonstrated a 20\% reduction in medical care expenditures for fully breast-fed babies as compared with babies who have never been breast-fed ${ }^{32}$.

The multitude of advantages of breast-feeding for the infant (nutritional, immunological and psychological) and nursing woman (physiological, psychological and emotional) makes nursing a gratifying experience for both mother and child. Additional factors such as the convenience of nursing, in that human milk is hygienic, readily available and without the need for preparation or heating, as well as being economical, reinforce breastmilk's position as the food of choice for infants.

\section{Breast-feeding}

Both mother and child participate in the act of nursing, and consequently breast-feeding success depends on the two of them. Women who, during pregnancy, have the desire and conviction to nurse can achieve it with sufficient support and encouragement. It is vitally important that their diet is adequate to meet the specific needs favouring milk production that will satisfy the nutrient requirements of the newborn. Another critical factor is the infant's suckling capacity, thus stimulating the initial secretion in the form of colostrum, which in turn evolves into mature breast-milk ${ }^{33}$.

Successful breast-feeding begins during pregnancy, involving both a nutritional factor for building nutrient reserves in the preparation for nursing, as well as a psychological component, which takes into account the desire and willingness to breast-feed. These are essential elements in order to achieve breast-feeding goals, and as 
Table 1 Recommended energy and nutrient intakes for the Spanish population (revised 1998; Department of Nutrition, Complutense University of Madrid ${ }^{39}$ )

\begin{tabular}{|c|c|c|c|c|c|}
\hline & \multirow[b]{2}{*}{ Women 20-39 years } & \multicolumn{2}{|c|}{ Pregnancy } & \multicolumn{2}{|c|}{ Lactation } \\
\hline & & 2nd half & Adolescent & Adult & Adolescent $^{\star}$ \\
\hline Energy & $\begin{array}{l}2300 \mathrm{kcal} \\
9623 \mathrm{~kJ}\end{array}$ & $\begin{array}{r}+250 \mathrm{kcal} \\
+1046 \mathrm{~kJ}\end{array}$ & $\begin{array}{l}+300 \mathrm{kcal} \\
+1300 \mathrm{~kJ}\end{array}$ & $\begin{array}{l}+500 \mathrm{kcal} \\
+2092 \mathrm{~kJ}\end{array}$ & $\begin{array}{l}+500 \mathrm{kcal} \\
+2100 \mathrm{~kJ}\end{array}$ \\
\hline Protein $(\mathrm{g})$ & 41 & +15 & +30 & +25 & +20 \\
\hline Calcium (mg) & 800 & +600 & - & +700 & - \\
\hline Iron (mg) & 18 & 18 & - & 18 & - \\
\hline lodine $(\mu \mathrm{g})$ & 110 & +25 & - & +45 & - \\
\hline Zinc (mg) & 15 & 20 & - & 25 & - \\
\hline Magnesium (mg) & 330 & +120 & - & +120 & - \\
\hline Thiamine (mg) & 0.9 & +0.1 & +0.4 & +0.2 & +0.5 \\
\hline Riboflavin (mg) & 1.4 & +0.2 & +0.3 & +0.3 & +0.5 \\
\hline Niacin equivalents (mg) & 15 & +2 & +2 & +3 & +5 \\
\hline Vitamin $\mathrm{B}_{6}(\mathrm{mg})$ & 1.6 & +2 & +0.6 & +1.5 & +0.5 \\
\hline Folic acid $(\mu \mathrm{g})$ & 200 & +200 & +400 & +100 & +100 \\
\hline Vitamin $B_{12}(\mu \mathrm{g})$ & 2 & 2.2 & +1.0 & 2.6 & +1.0 \\
\hline Vitamin C (mg) & 60 & 80 & +20 & 85 & +40 \\
\hline Vitamin $A$, retinol equivalents $(\mu \mathrm{g})$ & 800 & 800 & +200 & 1.300 & +400 \\
\hline Vitamin D $(\mu \mathrm{g})$ & 5 & 10 & +5 & 10 & +5 \\
\hline Vitamin E (mg) & 12 & +3 & +2 & +5 & +3 \\
\hline
\end{tabular}

* National Research Council, USA (1990).

such, appropriate personal and environmental surroundings should be considered and encouraged.

Protein and lipid reserves accumulated during pregnancy are of special importance as they constitute an indispensable condition for optimal milk production, which is not obtained if meeting nutrient recommendations occurs postpartum. As is well known, two hormones orchestrate human milk production: prolactin, which acts on mammary glands; and oxytocin, the release of which is stimulated by the infant's suckling and thus promotes the necessary contractions for milk secretion ${ }^{34}$.

The World Health Organization (WHO) in their 45th World Health Assembly (May 1992) adopted the Innocenti Declaration in order to promote the practice of breastfeeding. More recently, in 1998, its Division of Child Health and Development published The Baby Friendly Hospital Initiative that includes 'The Ten Steps to Successful Breastfeeding'. Steps 2, 3 and 10 of this important document are worth highlighting ${ }^{35}$ :

- Step 2 - Train all health care staff in skills necessary to implement this policy.

- Step 3 - Inform all pregnant women about the benefits and management of breast-feeding.

- Step 10 - Foster the establishment of breast-feeding support groups and refer mothers to them on discharge from the hospital or clinic.

Health professionals play a vital role in supporting the nursing mother and should be aware of their influence towards promoting breast-feeding initiation and success. The practice of lactation, as other processes in life, needs to be learned and is not innate knowledge for the firsttime breast-feeder ${ }^{36}$.

\section{Nutritional needs of the breast-feeding woman}

As in pregnancy, the nursing mother first needs to focus on meeting her nutritional requirements as well as the extra physiological demands ${ }^{37}$. According to Fernández Ballart $^{38}$, 'key determinants at this stage are the composition and volume of secreted milk along with the nutritional status of the mother at the onset of this phase'.

The energy required to produce 1 litre of milk is estimated as around $700 \mathrm{kcal}$. As a consequence, current recommendations include increasing intake above the pre-pregnant requirements by $500 \mathrm{kcal} \mathrm{day}^{-1}$. Increased energy demands should be met in order to ensure coverage of other nutrient requirements as outlined in Table $1^{39}$. To this end, servings are increased from food groups that are more apt to provide nutrient as well as caloric adequacy.

\section{Nutritional needs of the breast-fed infant}

The quantity and quality of milk produced by a nursing woman depends on a variety of determinants, ranging from nutritional factors, emotional state and the infant's ability to suckle. Insufficient or inadequate food intake increases the fatigue common in postpartum women. Mothers of newborns often have to reorganise their personal and family life, adapt to fewer hours of sleep due to the frequency of nursing required at the onset of breast-feeding and deal with the often self-imposed pressure of their ability to 'be a good mother', especially with first-born children.

A breast-fed infant's nutritional requirements can be entirely met exclusively by breast-feeding during the first six months of life. At this time, solid foods should be 
Table 2 Recommended food servings/portion sizes and their nutrient contributions

\begin{tabular}{|c|c|c|c|c|c|}
\hline Food group & $\begin{array}{l}\text { Female } \\
\text { adult }\end{array}$ & $\begin{array}{l}\text { Pregnant } \\
\text { woman }\end{array}$ & $\begin{array}{l}\text { Breast-feeding } \\
\text { woman }\end{array}$ & Main food sources & Principal nutrients \\
\hline Breads and cereals & $3-6$ & $4-5$ & $4-5$ & $\begin{array}{l}\text { Bread, pasta, rice, legumes, } \\
\text { cereals, potatoes, etc. }\end{array}$ & $\begin{array}{l}\text { Carbohydrates (complex), } \\
\text { vitamins (B group) and fibre }\end{array}$ \\
\hline Vegetables & $2-3$ & $2-4$ & $2-4$ & $\begin{array}{l}\text { Wide variety based on seasonal } \\
\text { availability } \\
\text { Include salads daily }\end{array}$ & $\begin{array}{l}\text { Vitamins, minerals, water } \\
\text { and fibre }\end{array}$ \\
\hline Fruit & $2-3$ & $2-3$ & 23 & $\begin{array}{l}\text { Wide variety based on seasonal } \\
\text { availability }\end{array}$ & $\begin{array}{l}\text { Vitamins, minerals, water } \\
\text { and fibre }\end{array}$ \\
\hline Dairy products & $2-4$ & $3-4$ & $4-5$ & $\begin{array}{l}\text { Milk, fermented milk products \& cheese } \\
\text { (low-fat products preferred) }\end{array}$ & Proteins, fats and calcium \\
\hline Protein foods & $1 \frac{1}{2}-2 \frac{1}{2}$ & $2 \frac{1}{2}$ & $2 \frac{1}{2}$ & $\begin{array}{l}\text { Meat, poultry, fish, eggs } \\
\text { Legumes, nuts and cereals }\end{array}$ & $\begin{array}{l}\text { Proteins (of varying biological } \\
\text { value) } \\
\text { Lipids (of vegetable or animal } \\
\text { origin) } \\
\text { Vitamin } \mathrm{B}_{12} \text {, iron and fibre }\end{array}$ \\
\hline Added fats & $3-5$ & 4 & 4 & Preferably olive and/or seed oils & Lipids, vitamin E \\
\hline Water & $>2$ & $4-6$ & $6-8$ glasses & $\begin{array}{l}\text { Tap and bottled water, herbal teas } \\
\text { and non-alcoholic beverages with low } \\
\text { sugar content }\end{array}$ & Water \\
\hline
\end{tabular}

progressively introduced into the diet, supplemented by breast-milk or infant formula. As the period of lactation may last a significant length of time, it is important for the nursing woman to adequately plan her diet to meet nutritional requirements ${ }^{40}$.

\section{Dietary recommendations}

Dietary guidelines for the breast-feeding women encompass principles that also apply towards achieving a balanced diet: variety, balance, as well as being pleasurable and adequate to meet needs. To this end it is recommended to include these basic food groups on a daily basis: grains and cereals, fruits, vegetables, dairy products and protein foods. It is also critical to ensure an adequate state of hydration in the form of healthy beverages to optimise milk production. Table 2 outlines the food groups and daily servings recommended for adult women and breast-feeding mothers.

\section{Food and nutrient equivalents}

Dietary recommendations in the form of servings or portions are utilised internationally. This constitutes the most practical system as it takes into account common household measures and allows for establishing equivalents among distinct foods with similar nutrient composition. The Program of Alimentation and Nutrition (PAN 1.0) contains much of this data with specific foods for Spain, which also expresses content in common household measures as well as in grams ${ }^{41}$.

\section{Daily meal plans}

As in pregnancy, dietary guidelines should also include a series of practical suggestions. These include eating small, frequent meals, with each meal including the maximum number of food groups. Encouraging nursing women to drink fluids in abundance is also advised, which include water and other healthy beverages. The mother should watch for favourable or adverse reactions after feeding that could be related to her preceding food intake. If she is overweight, the diet should be adapted in such a way that meeting nutritional needs would not be jeopardised. For an underweight mother who has difficulty consuming the recommended intakes, enriched foods or food supplements should be considered, especially in the case of calcium.

\section{Special considerations}

Pregnancy and lactation constitute a period of life in which popular beliefs and practices abound, and even though some may have historical explanations that are more or less plausible, others should be demystified and placed in a current context. For example, mothers should be reminded that not one specific food in and of itself increases milk production, but rather the adequate combination of foods in their totality.

It is known that breast-milk can vary in taste, colour and can even affect the infant's digestive function. This is due to the composition of the mother's diet and the inclusion of the following foods: artichokes, onions, asparagus, turnips, leeks, garlic, peppers, vegetables (from the cabbage family) and legumes. However, before automatically eliminating these foods from the diet, it is recommended to observe the infant's reactions after feeding, as responses vary widely and may not even occur. In the case of children who have a family history of allergies, it may be prudent for the mother to avoid foods that are known to be potential allergens such as berries, tropical fruits, chocolate, fatty fish, cow's milk and eggs $^{42,43}$.

Maternal milk is a mammary secretion and, as such, one 
must keep in mind that milk glands eliminate certain substances that may later be excreted in milk. Examples of such substances include alcohol, nicotine and compounds from a variety of medications. Therefore it is prudent to recommend abstaining from alcohol and tobacco, as well as non-prescribed medications, during lactation. For mothers unwilling or unable to stop smoking, breast-feeding is still recommended as its benefits outweigh the disadvantages of nicotine exposure. Finally, it is advisable to limit caffeine and caffeinecontaining products to two cups or less per day, as hyperactivity, fussiness and colic have been reported in some infants whose mothers are regular drinkers of caffeine-containing beverages ${ }^{44}$.

\section{The period after lactation}

After pregnancy, delivery and lactation, it is recommended to slowly return to one's normal eating pattern as the supplementary nutritional demands produced by these physiological changes are no longer present. Certain habits are worth maintaining, especially the focus on consuming complex carbohydrates, vegetables and fruits, water and the predominance of vegetable versus animal fats. The intake of dairy products and protein foods should be reduced. Very often the periods of pregnancy and breast-feeding are the best times to restructure pre-existing inadequate eating habits. Positive changes would not only benefit the mother but also the rest of the family as well as the newborn, having farreaching effects into the future: childhood, adolescence and adulthood.

\section{Conclusion}

The nutritional status of the breast-feeding woman is of vital importance. However, adequate nutrition clearly begins during pregnancy, the biological cycle that is specific for the accumulation of reserves. This can only be achieved with adequate and personalised dietary counselling which orients food intake to cover nutritional needs specific for each physiological condition. In summary, it is worth pointing out that this solid nutritional base for nursing should be reinforced by the mother's predisposition and attitude, the adequate suckling of the newborn and the support of her partner and/or family. With all of these facilitating conditions, breast-feeding is guaranteed to be a success.

\section{References}

1 Fomon S. Nutrición del Lactante. Madrid: Mosby/Doyma, 1995.

2 Lawrence R. La Lactancia Materna: Una Guía para la Profesión Médica, 4th ed. Madrid: Mosby/Doyma, 1996

3 Van den Boom SAM, Kimber AC, Morgan JB. Type of milk feeding in infants and young children up to 19 months of age in three socio-economic groups in Madrid. Acta Paediatr. 1993; 82: 1017-23.

4 Dirección General de Salud Pública. Encuesta Nacional de Salud de España 1995. Madrid: Ministerio de Sanidad y Consumo, 1996.

5 Dirección General de Salud Pública. Encuesta Nacional de Salud de España 1997. Madrid: Ministerio de Sanidad y Consumo, 1998.

6 Instituto Nacional de Estadística (INE). Indicadores Sociales de España. Encuesta de Población Activa, 1999. Madrid: INE, 2000.

7 US Department of Health and Human Services. HHS Blueprint for Action on Breastfeeding. Washington, DC: US Department of Health and Human Services, Office of Women's Health, 2000.

8 Picciano MF. Human milk: nutritional aspects of a dynamic food. Biol. Neonate 1998; 74: 84-93.

9 Dewey KG. Growth characteristics of breast-fed compared to formula-fed infants. Biol. Neonate 1998; 74: 94-105.

10 Elliott KG, Kjolhede CL, Gournis E, Rasmussen KM. Duration of breastfeeding associated with obesity during adolescence. Obes. Res. 1997; 5(6): 538-41.

11 Oken E, Lightdale JR. Updates in pediatric nutrition. Curr. Opin. Pediatr. 2000; 12(3): 282-90.

12 Norris JM, Scott FW. A meta-analysis of infant diet and insulin-dependent diabetes mellitus: do biases play a role? Epidemiology 1996; 7(1): 87-92.

13 Pettitt DJ, Forman MR, Hanson RL, Knowler WC, Bonnett $\mathrm{PH}$. Breastfeeding and incidence of non-insulin-dependent diabetes mellitus in Pima Indians. Lancet 1997; 350: 166-8.

14 Greco L, Auricchio S, Mayer M, Grimaldi M. Case control study on nutritional risk factors in celiac disease. J. Pediatr. Gastro. Nutr. 1997; 7(3): 395-9.

15 Falth-Magnusson K, Franzen L, Jansson G, Laurin P, Stenhammar L. Infant feeding history shows distinct differences between Swedish celiac and reference children. Pediatr. Allergy Immunol. 1996; 7(3): 1-5.

16 Ascher H, Krantz I, Rydberg L, Nordin P, Kristiansson B. Influence of infant feeding and gluten intake on celiac disease. Arch. Dis. Child. 1997; 76: 113-7.

17 Koletzko S, Sherman P, Corey M, Griffiths A, Smith C. Role of infant feeding practices in development of Crohn's disease in childhood. BMJ 1989; 298: 1617-8.

18 Shu XO, Linet MS, Steinbuch M, Wen WO, Buckley JD, Neglia JP, Potter JD, Reaman GH, Robinson Ll. Breastfeeding and risk of childhood acute leukemia. J. Natl. Cancer Inst. 1999; 91(20): 1765-72.

19 Gruber M, Marshall JR, Zielezney M, Lance P. A casecontrol study to examine the influence of maternal perinatal behaviors on the incidence of Crohn's disease. Gastroenterol. Nursing 1996; 19(2): 53-9.

20 Saarinen UM, Kajosaari M. Breastfeeding as prophylaxis against atopic disease: prospective follow-up study until 17 years old. Lancet 1995; 346: 1065-9.

21 Oddy WH, Holt PG, Sly PD, Read AW, Landau LI, Stanley FJ, Kendall GE. Association between breast feeding and asthma in 6 year old children: findings of a prospective birth cohort study. BMJ 1999; 319: 815-9.

22 Burr ML, Limb ES, Maguire MJ, Amarah L, Eldridge BA, Layzell JC, Merrett TG. Infant feeding, wheezing, and allergy: a prospective study. Arch. Dis. Child. 1993; 68: $724-8$.

23 Anderson EW, Johnstone BM, Remax DT. Breastfeeding and cognitive development: a meta-analysis. Am. J. Clin. Nutr. 1999; 70: 525-35.

24 Jacobson SW, Chiodo LM, Jacobson JL. Breastfeeding effects on intelligence quotient in 4- and 11-year-old children. Pediatrics 1999; 103(5): 71

25 Jorgensen MH, Hernell O, Lund P, Holmer G, Michaelsen 
KF. Visual acuity and erythrocyte docosahexaenoic acid status in breastfed and formula-fed term infants during the first four months of life. Lipids 1996; 31(1): 99-105.

26 Hamosh M, Salem N. Long-chain polyunsaturated fatty acids. Biol. Neonate 1998; 74: 106-20.

27 Heinig MJ, Dewey KG. Health effects of breastfeeding for mothers: a critical review. Nutr. Res. Rev. 1997; 10: 35-56.

28 Kuzela AL, Stifter CA, Worobey J. Breastfeeding and mother-infant interactions. J. Reprod. Infant. Psychol. 1990; 8: 185-94.

29 Windstrom AM, Wahlberg V, Matthiesen AS, Eneroth P, Uvnas-Moberg K, Werner S, Winberg J. Short-term effects of early suckling and touch of the nipple on maternal behavior. Early Hum. Dev. 1990; 21: 153-63.

30 Virden SF. The relationship between infant feeding method and maternal role adjustment. J. Nurs. Midwif. 1988; 33(1): $31-5$.

31 Montgomery DL, Splett PL. Economic benefit of breastfeeding infants enrolled in WIC. J. Am. Diet. Assoc. 1997; 97: 379-85.

32 Hoey C, Ware JL. Economic advantages of breast-feeding in an HMO setting: a pilot study. Am. J. Man. Care 1997; 3(6): $861-5$.

33 Cervera P. Alimentación Maternoinfantil, 2th ed. Barcelona: Masson, 2000.

34 Cervera P, Trias E. Alimentación y nutrición. In: Bras J, de la Flor JE, Masvidal RM, eds. Pediatría en Atención Primaria. Barcelona: Springer-Verlag Ibérica, 1997.

35 Organización Mundial de la Salud (OMS), División de Salud y Desarrollo del Niño. Pruebas Científicas de los Diez Pasos Hacia una Feliz Lactancia Natural. Ginebra: OMS, 1998.

36 Associació Catalana Pro Alletament Matern. Lactancia Materna: Manual para Profesionales, 2th ed. Barcelona: Associació Catalana Pro Alletament Matern, 1994.

37 Courpotin C, Girardet JP, Machinot S. La Alimentación del Lactante. Barcelona: Labor, 1981.

38 Fernández Ballart JD. Nutrición durante el embarazo y la lactancia. In: Serra Ll, Aranceta J, Mataix J, eds. Nutritición y Salud Pública: Métodos, Bases Científicas y Aplicaciones. Barcelona: Masson, 1995.

39 Departamento de Nutrición. Ingestas Recomendadas de Energía y Nutrientes para la Población Española. Madrid: Universidad Complutense de Madrid, 1998.

40 Committee on Nutrition. Nutrition during Lactation [Summary, Conclusions and Recommendations]. Washington, DC: National Academy Press, 1991.

41 CESNID/Ndiet Soft. PAN: Programa de Alimentación y Nutrición, Versión 1.0 para Windows 95/98. Barcelona: CESNID/Ndiet Soft SL, 2000.

42 Spisak S, Gross SS. Breastfeeding and Human Lactation. Washington, DC: National Center for Education in Maternal and Child Health, 1991.

43 Bofill A, Vilaplana M, Rivero M. Manual de Dispensació de Llets Infantils. Barcelona: Collegi de Farmacèutics de la Província de Barcelona, 1996.

44 Stone M. Nutrition during pregnancy and lactation. In: Mahan K, Escott-Stump S, eds. Krause's Food, Nutrition and Diet Therapy, 9th ed. Philadelphia, PA: WB Saunders Co., 1996. 